\title{
Spinal Cord Column
}

National Cancer Institute

\section{Source}

National Cancer Institute. Spinal Cord Column. NCI Thesaurus. Code C33588.

Any of the four main columns of gray matter, which are located in the spinal cord, and which are composed primarily of neuronal cell bodies and neurog lia. 